\title{
A decade of annual Arctic DOC export with Polar Surface Water in the East Greenland Current
}

GonçalvesAraujo, Rafael; Stedmon, Colin A.; Steur, Laura; Osburn, Christopher L.; Granskog, Mats A.

Published in:

Geophysical Research Letters

Link to article, DOI:

10.1029/2020GL089686

Publication date:

2020

Document Version

Peer reviewed version

Link back to DTU Orbit

Citation (APA):

GonçalvesAraujo, R., Stedmon, C. A., Steur, L., Osburn, C. L., \& Granskog, M. A. (2020). A decade of annual Arctic DOC export with Polar Surface Water in the East Greenland Current. Geophysical Research Letters, 47(20), [e2020GL089686]. https://doi.org/10.1029/2020GL089686

\section{General rights}

Copyright and moral rights for the publications made accessible in the public portal are retained by the authors and/or other copyright owners and it is a condition of accessing publications that users recognise and abide by the legal requirements associated with these rights.

- Users may download and print one copy of any publication from the public portal for the purpose of private study or research.

- You may not further distribute the material or use it for any profit-making activity or commercial gain

- You may freely distribute the URL identifying the publication in the public portal 
Gonçalves-Araujo Rafael (Orcid ID: 0000-0001-8344-8326)

Stedmon Colin, A (Orcid ID: 0000-0001-6642-9692)

de Steur Laura (Orcid ID: 0000-0002-6043-7920)

Osburn Christopher, L. (Orcid ID: 0000-0002-9334-4202)

Granskog Mats, Anders (Orcid ID: 0000-0002-5035-4347)

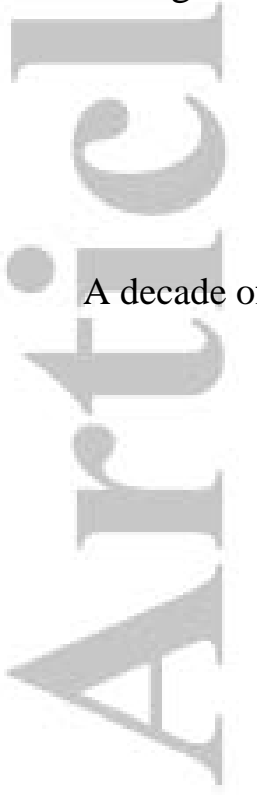

Running head: East Greenland Current DOC export

${ }^{1}$ National Institute of Aquatic Resources, Technical University of Denmark, Kgs. Lyngby, Denmark

${ }^{2}$ Norwegian Polar Institute, Troms $\emptyset$, Norway

${ }^{3}$ Department of Marine, Earth, and Atmospheric Sciences, North Carolina State University, Raleigh,

NC, USA

Keywords: CDOM absorption slope; current velocity; volume transport; ocean mooring; Polar

Surface Water; Fram Strait

\section{Key Points:}

- Spectral characteristics of CDOM can predict DOC concentrations in the Fram Strait

- DOC transports are strongly correlated with Polar Surface Water volume transports from the Arctic Ocean with the East Greenland Current

- Annual DOC transport estimates for 2009 to 2018 varied between 27 and $60 \mathrm{Tg} \mathrm{C} \mathrm{yr}^{-1}$

This article has been accepted for publication and undergone full peer review but has not been through the copyediting, typesetting, pagination and proofreading process which may lead to differences between this version and the Version of Record. Please cite this article as doi: 10.1029/2020GL089686 


\begin{abstract}
The export of dissolved organic carbon (DOC) from the Arctic Ocean is expected to change due to warming and increased river runoff. Here we present a method to quantify DOC transport with the East Greenland Current combining synoptic and year-round data (2009-2018). An algorithm based on quantitative and qualitative aspects of colored dissolved organic matter (CDOM) was developed to provide DOC estimates. Combined with mooringderived monthly Polar Surface Water (PSW) volume transports, we estimate DOC exports for the period from 2003-2017. For much of the period DOC exports have been reasonably constant at $46.8( \pm 6.2) \mathrm{Tg} \mathrm{yr}^{-1}$, while the reduction in PSW export in recent years has resulted in lower annual DOC exports (below $39 \mathrm{Tg} \mathrm{C} \mathrm{yr}^{-1}$ ). We now have a technique to resolve seasonal and annual fluctuations in Arctic carbon export, offering a significant improvement over earlier bulk estimates and represents a baseline to detect future change.
\end{abstract}

\title{
Plain language summary
}

The Arctic Ocean has higher concentrations of dissolved organic carbon (DOC) compared to the other oceans due to the supply from large Siberian rivers that drain expansive carbon-rich watersheds. Climate change in the Arctic is altering the supply of river water and DOC to the Arctic Ocean. This is eventually expected to also be reflected in the subsequent export of DOC from the Arctic to the North Atlantic via a major gateway, the Fram Strait. Here we present a new approach to quantify the transport of DOC through the Fram Strait based on year-round mooring data and spectroscopic measurements of colored dissolved organic matter (CDOM). We calculate DOC transports using our measurements over a 10-year period and the results provide a baseline from which to observe future changes in the Arctic Ocean that were not resolved with earlier estimates based on bulk concentrations and bulk volume transports.

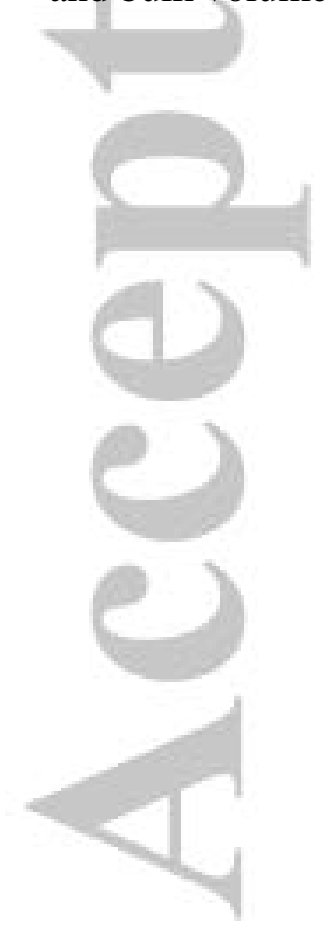




\section{Introduction}

The Arctic Ocean and its drainage basins are experiencing rapid change. Changes in the cryospheric components, especially sea ice and permafrost, as well as the hydrological cycle will likely have significant but largely unknown integrated effects on carbon cycling (e.g., Parmentier et al., 2017; Vonk \& Gustafsson, 2013). The Arctic Ocean receives a disproportionally large input of dissolved organic carbon (DOC), equating to approximately $15 \%$ of global riverine DOC supply to the oceans (Dai et al., 2012), although its volume is only $1 \%$ of the global ocean. Thawing permafrost has the potential to release vast amounts of carbon from Arctic soils since they contain 50\% of global soil carbon (Parmentier et al., 2017). At the same time, increasing coastal and subsea erosion play an important role as additional sources of ancient carbon (Vonk et al., 2012) and, further, $\mathrm{CO}_{2}$ to the coastal Arctic (Tanski et al., 2019). Along with that, the shrinking sea ice leads to increase in net primary production in the Arctic Ocean (Arrigo \& van Dijken, 2011), which has direct implications to the production of marine colored dissolved organic matter (CDOM) (RomeraCastillo et al., 2010) and further to the microbial food web (Aarnos et al., 2012). This emphasizes the importance of understanding the cycling and fate of organic carbon in the Arctic Ocean.

One significant component of the Arctic carbon budget is the export to the North Atlantic which acts as a sink for the Arctic Ocean. This flux is estimated to be evenly split between the East Greenland Current (EGC) in Fram Strait and the transport through the Canadian Arctic Archipelago (Anderson \& Amon, 2015). However, for both export pathways the existing estimates of carbon transports are crude and based on disparate synoptic DOC concentrations and estimated mean bulk volume transports reported in the literature. These existing estimates do not take into account significant spatial gradients in neither DOC or velocities across the Fram Strait (cf. Granskog et al., 2012) nor seasonal to interannual variability in volume transports. Resulting DOC export estimates within the EGC range from 30 to $40 \mathrm{Tg} \mathrm{C} \mathrm{y}^{-1}$ (Amon, 2004; Anderson \& Amon, 2015; Opsahl et al., 1999), and are greatly dependent on the magnitude of the volume transports employed and cannot be used to detect possible changes in the DOC exports. The estimates for the total riverine input to the Arctic Ocean also vary significantly, from between 18 to $36 \mathrm{Tg} \mathrm{C} \mathrm{y}^{-1}$ (Amon, 2004; Anderson, 2002; Anderson \& Amon, 2015; Dai et al., 2012; Dittmar \& Kattner, 2003; Opsahl et al., 1999; Raymond et al., 2007; Stein \& Macdonald, 2004). Given the large uncertainty in nearly every component of the Arctic Ocean carbon budget, these estimates need to be better constrained. This, in combination with improved model representation of relevant biogeochemical processes, is essential to improve the capacity to forecast future conditions (Parmentier et al., 2017).

In order to provide an appropriate baseline upon which to assess future changes in Arctic Ocean DOC exports, a more refined approach is required. Here we use measurements from the Arctic Outflow Observatory in Fram Strait (http://www.npolar.no/framstrait) to quantify the DOC export with Polar Surface Water (PSW) in the EGC in the ten-year period from 2009 to 2018. Further, our findings allow us to extrapolate the time series to obtain an estimate of DOC transport since 2003. DOC concentrations were estimated based on 
measurements of the spectral absorption properties of CDOM. DOC export estimates were then obtained by combining with upper ocean volume transports of PSW in the EGC from coincident mooring data (de Steur et al., 2018). This approach provides a contemporary estimate of the DOC transport with the EGC to the North Atlantic and provides a measure of its seasonal and interannual variability. The results also offer insight into how these estimates could be improved further with contemporary and future autonomous platforms.

\section{Sampling and Methods}

The data used here were collected during ten annual cruises in August-September 20092018 across the Fram Strait (including the EGC) at about $78.8^{\circ} \mathrm{N}$ by the Norwegian Polar Institute (cf. Gonçalves-Araujo et al., 2016; Granskog et al., 2012). Stations were taken each year typically at a half or one degree spacing in longitude (Fig. 1). At each station, conductivity-temperature-depth (CTD) profiles were obtained with a calibrated Seabird SBE911+ profiler and seawater samples were collected with SBE32 Carousel Water Sampler equipped with 12 Niskin bottles. Separate water samples for salinity measurement were drawn from the Niskin bottles immediately after the CTD package was on deck. These salinity samples were analyzed at sea using a Guildline Portasal salinometer with an accuracy of 0.003 . When needed, the CTD conductivity data were calibrated against bottle salinity measurements.

Sampling also included CDOM and DOC (same depths as salinity), with sampling targeting the upper 400 meters (typical target depths were 1, 5, 15, 25, 50, 75, 100, 150, 200, 250 and $400 \mathrm{~m}$ ). Each year, between 200-430 CDOM samples were collected from the region with at least 200 stemming from the transect at $78.8^{\circ} \mathrm{N}$, whilst the remainder came from additional transects on the Greenland Shelf from polar water masses. CDOM absorbance was measured spectrophotometrically as described in Granskog et al. (2012). In 2009, 2010, 2012, 2014 and 2016 approximately 180-230 samples for DOC analysis were collected each year. These samples were collected directly into acid-washed high-density polyethylene bottles (HDPE) and stored frozen. Carbon content in 2009-2012 was quantified using a Shimadzu TOC-VCPH analyzer after acidification to $\mathrm{pH} 2$ and sparging oxygen. In 2014-2016 it was measured on an OI Analytical 1030D TOC analyzer after acidification to $\mathrm{pH} 2$ and sparging with ultrahigh purity helium. Reproducibility between the two instruments was confirmed to be $<5 \%$ with replicate measurements of samples from 2014. The accuracy of quantification was controlled by analyzing the Hansell seawater DOC consensus reference material (CRM). These samples were not filtered, and therefore technically represent TOC. For surface waters $(<50 \mathrm{~m})$ plankton and detritus can contribute with particulate organic carbon (POC).

However, a comparison of total and dissolved light attenuation in the region has shown that the concentration of particulates in the western Fram Strait is very low (Granskog et al., 2015; Pavlov et al., 2015). This contrasts the situation east of the meridian where northward flowing surface Atlantic waters have lower background DOC $(50-70 \mu \mathrm{M})$ and detectable POC (>5 $\mu \mathrm{M})$ (Engel et al., 2019; Pavlov et al., 2015). 


\section{Velocity fields and PSW volume transport estimates}

To provide estimates of a synoptic volume transport for a 30 day period in AugustSeptember across the Fram Strait, geostrophic velocities were derived from the CTD measurements gathered during the annual cruises in the Fram Strait (2009-2018). These were referenced to a 30-day mean, vertically-averaged velocity obtained from the moored instruments, which had been corrected for tides. This approach resulted in a velocity field across the section which could be used to calculate synoptic volume transport and later, once combined with DOC fields, carbon fluxes. PSW was defined as water with temperature $<0{ }^{\circ} \mathrm{C}$ and density $<27.7 \mathrm{~kg} \mathrm{~m}^{-3}$ (Rudels et al., 1999), (see black and dashed contours, respectively, in Figure 1). Synoptic volume transport of PSW was calculated by integrating transport for waters with these properties across $8^{\circ} \mathrm{W}$ to $1^{\circ} \mathrm{W}$ at $78.8^{\circ} \mathrm{N}$.

Measurements from the oceanographic moorings maintained in the Arctic Outflow Observatory by the Norwegian Polar Institute since 2002 were used to derive estimates of monthly PSW volume transports for all years. The moorings collect temperature, salinity and velocity data at 15-minute to hourly intervals at selected depths (de Steur et al., 2018) (Fig. 1). Data gaps (1-2 weeks) arising from servicing the moorings were filled by a linear interpolation in time. To incorporate realistic stratification in the vertical, the mooring time series are complemented with CTD hydrography. Extrapolation upward to the surface from the uppermost moored instrument (at target depth $55 \mathrm{~m}$ ) and between this level and the next instrument down (at target depth $250 \mathrm{~m}$ ) is carried out as follows: levels at $5 \mathrm{~m}, 25 \mathrm{~m}$, and $155 \mathrm{~m}$ are inserted and salinity is determined here from regression of the instrument time series with a monthly, seasonally varying climatology obtained from all available CTD data between 1997 and 2018. Thereafter the data are linearly interpolated in the vertical. In the horizontal, the data between the mooring sites are interpolated at $5 \mathrm{~km}$ horizontal distance on terrain-following contours. As with the synoptic transport estimates explained above, the monthly volume transports of PSW were calculated by integrating the mooring velocity field data for water with PSW characteristics, across $8^{\circ} \mathrm{W}$ to $1^{\circ} \mathrm{W}$ at $78.8^{\circ} \mathrm{N}$. These PSW transports are based on the same data set used for earlier freshwater transports (FWT) (de Steur et al., 2018), but now are updated to extend to August 2017.

These two approaches allow us to examine how well scaling up the synoptic volume transport obtained in later summer fits with the mooring-based annual volume transports. The latter approach, with continuous measurements taken over the year, should provide a more accurate annual volume transport estimate. Both approaches offer an improvement on current estimates as they allow to resolve interannual changes in fluxes.

\section{Deriving DOC from CDOM measurements}

In order to derive estimates of DOC export across the EGC it is important to have good spatial and temporal coverage. In our Fram Strait expeditions, DOC data were lacking in some years, while in other years there was sparse geographical coverage. As a result, we investigated the relationship between CDOM spectral absorption and DOC concentrations where these data were available (Fig. 2; Table 1). In regions in close proximity to rivers, 
linear relationships between CDOM absorption at $350 \mathrm{~nm}, \mathrm{a}_{350}$, and DOC often can be found (Gonçalves-Araujo et al., 2015; Spencer et al., 2012; Vodacek et al., 1997). Regional variability in river-influenced coastal margins limits wide application of these simple linear relationships between DOC and CDOM $\mathrm{a}_{350}$; thus, the use of coefficients that describe spectral absorption of CDOM have improved prediction of DOC using two endmembers (Fichot \& Benner, 2011). However, in regions with two or more endmembers of more comparable DOC concentrations (shelf seas and oceanic waters) these relationships are difficult to derive (Fig. 2a). Essentially, there might be two pools of similar concentration/intensity but different ratio of absorption to DOC (carbon specific absorption coefficient, $\left.\mathrm{a}^{*}\right)$. Earlier work has identified inverse relationships between $\mathrm{a}^{*}$ and the spectral slope coefficient of CDOM absorption between 275-295 nm ( $\left.\mathbf{S}_{275-295}\right)$ (summarized in Stedmon \& Nelson, 2015). For the Fram Strait, we found that the following relationship to predict DOC concentrations (pDOC) holds:

$$
\mathrm{pDOC}=\mathrm{a}_{350} \times 10^{\mathrm{n}},
$$

where $\mathrm{n}=\left(\mathrm{C}+\mathrm{M} * \mathrm{~S}_{275-295}\right)($ Fig. $2 \mathrm{~d})$. We found that $\mathrm{C}=0.549$ and $\mathrm{M}=0.0709$ (RMSE=0.13; $r=0.82 ; p<0.0001 ; n=864)$. This relationship implies that there is a linear correlation between DOC and $\mathrm{a}_{350}$ (Fig. 2b), but that the slope of the relationship (inverse of $\mathrm{a}^{*}$ ) varies depending on the exponent of the ultraviolet (UV) spectral slope $\left(\mathrm{S}_{275-295}\right)$, i.e., character or source of DOM (Fig. 2c). This factor therefore can incorporate the fact that samples with low $\mathrm{S}_{275-295}$, which often represent terrestrial material (Helms et al., 2008) have a higher a* than aged marine DOM, which is characterized with higher $\mathrm{S}_{275-295}$ and lower a* (Stedmon \& Nelson, 2015). Using the relationship shown in Fig. $2 d$ we are able to predict DOC across the strait for all years based on the CDOM measurements (Fig. 1). This indicates that the algorithm is capable of capturing variability of DOC in the contrasting marine waters, from Atlantic waters to Polar Waters, that are present in the Fram Strait (Pavlov et al., 2015). Finally, the $\mathrm{a}_{350}$ and pDOC values were linearly interpolated within the surface layer $(0-500 \mathrm{~m})$ across 8 ${ }^{\circ} \mathrm{W}$ to $1{ }^{\circ} \mathrm{W}$ over $1 \mathrm{~m}$ and $1 \mathrm{~km}$ intervals in the vertical and horizontal directions, respectively.

\section{Estimation of DOC export with the EGC Polar Surface Water}

Annual PSW DOC export with the EGC was estimated using two approaches. For the first approach, synoptic (August/September) DOC fields across the section were combined with the synoptic velocity field, then integrated for PSW to result in an estimate of synoptic DOC export. These data could then be scaled upwards to provide annual DOC export.

The second approach takes advantage of the strong significant correlation we find between the synoptic PSW DOC transports (derived from absolute geostrophic velocities, explained above) for August/September with the observed PSW volume transports estimates from moorings ( $r=0.97$; $p<0.0001$; Fig. 3a). Here, monthly PSW volume transports in the EGC derived from the mooring data were then used to estimate monthly PSW DOC transports (Fig. 3b) based on the relationship shown in Fig. 3a. Those monthly transports 
(Fig. 3b) were then summed up for each respective calendar year to provide the annual PSW DOC exports (Fig. 3c). This approach provides a more detailed estimate of PSW DOC transport as it takes into account month-to-month variations in volume transport of PSW in the EGC (rather than extrapolating August/September conditions across the year). The additional advantage of this method is that we can estimate the PSW DOC transport for years where CDOM and DOC were not sampled, thus allowing us to extrapolate the time series of PSW DOC transport back to 2003 (Fig. 3b and 3c). The resulting annual PSW DOC export estimates from both approaches are shown in Fig. 3c and Table 1.

The mean southward synoptic PSW volume transports with the EGC varied between 0.29 and 1.34 Sv, and the mean synoptic DOC export with PSW varied from $0.29-1.39 \mathrm{Mg} \mathrm{s}$ ${ }^{1}$ for August/September 2009 to 2018 (Table 1; Fig. 3a). The annual DOC export estimates based on the synoptic approach varied between 9 and $44 \mathrm{Tg} \mathrm{yr}^{-1}$ (from 2009 to 2018) and from 27 to $60 \mathrm{Tg} \mathrm{yr}^{-1}$ (between 2003 and 2017) based on the mooring approach (Table 1; Fig. $3 c)$. There was no significant trend observed for the study period considering both approaches ( $p>0.05)$. Yet, the mooring approach shows a progressive decrease in the annual PSW DOC export starting from 2015. The cumulative DOC export between 2009-2017 amounted to 234 and $390 \mathrm{Tg} \mathrm{C}$ for the synoptic and mooring approaches, respectively (Fig. 3c). The cumulative flux for the whole period, 2003 to 2017, is $656 \mathrm{Tg}$ C. Although the estimated annual PSW DOC export values span the range of previous bulk estimates (Anderson \& Amon, 2015) (Table 1), there are points to note. The annual estimates based on synoptic velocities underestimate the PSW DOC fluxes for most years, with exception of 2016 (Fig. $3 c$ ). This leads to an underestimation of $40 \%$ of the cumulative PSW DOC transport (20092017) compared to the estimates obtained with the mooring approach utilizing year-round velocity data. The underestimation can be explained by much lower current velocities that prevail during the period of synoptic sampling (August/September). The expeditions take place in late summer (Fig. 3b), when the volume transport of the EGC is at its minimum (de Steur et al., 2014, 2018) due to weak wind forcing at that time of the year. Scaling these synoptic summer values to annual fluxes therefore results in an underestimation. This is also the likely reason for the mooring based estimates to be on average higher than previously reported values (Table 1). The mooring approach captures the seasonal variability of the EGC in the Fram Strait, which is characterized by strong southward flow in the winter and spring as well as high intra-annual fluctuations (Fahrbach et al., 2001; de Steur et al., 2014, 2018). Combined with more accurate representation of frontal regions with large gradients in DOC and current velocities, this approach provides the best currently available estimate of annual PSW DOC exports.

The underlying assumption for these estimates is that the relationship between PSW DOC and volume transport derived from synoptic measurements in August/September from 2009-2018 (Fig. 3a) is representative for the year as a whole. Support for this assumption can be found in the documented robust correlation between meteoric water and CDOM, in samples from several years in the western Fram Strait and further south along the east Greenland shelf (Granskog et al., 2012; Stedmon et al., 2015). Here the meteoric water contribution in the PSW mostly represents a river water contribution (Dodd et al., 2012). We 
also found that PSW DOC was strongly correlated with derived freshwater transports (FWT, following de Steur et al., 2018; $r=0.94 ; p<0.0001$; Fig. 3a). These correlations reflect the importance of Arctic rivers as a source of freshwater and DOC to the Arctic Ocean and the preservation of this riverine signal in surface and halocline waters during passage across the Arctic basin and to Fram Strait (Amon, 2004; Gonçalves-Araujo et al., 2016, 2018; Granskog et al., 2012; Stedmon et al., 2015). Here we refrain from reporting freshwater fluxes and report on PSW volume transport instead due to the recently documented large dependency of FWT estimates on the arbitrary choice of reference salinity (Schauer \& Losch, 2019). The approach we apply here (PSW DOC transport relationship) has the benefit of not being influenced by changes in the relationship between DOC and salinity across the year which can occur due to local melting of sea ice.

A likely source of uncertainty for our estimates is the lack of year-round measurements on the easternmost part of the east Greenland shelf and an appropriate estimate of net southward volume transports west of the mooring array. While synoptic summer sections show that there is southward transport of freshwater and hence DOC west of $8^{\circ} \mathrm{W}$, it is unknown how far west it extends, and for how much of the year it persists. A portion of this southward flow west of $10.6^{\circ} \mathrm{W}$ (Rabe et al., 2013), may recirculate northward again in the Norske Through on the Greenland shelf (cf. Granskog et al., 2012), and it may be highly seasonally variable. Therefore, the DOC transport estimates with PSW in the EGC between $1^{\circ}$ and $8^{\circ} \mathrm{W}$ presented here are likely in the lower range of expected exports. An extension of the mooring array further across the shelf and including DOM measurements would be beneficial for refining estimates.

A recent summary of the Arctic DOC budget has shown that it is still unclear if the Arctic Ocean is a net source or sink of DOC. The uncertainties associated with the ocean fluxes in particular are high (Anderson \& Amon, 2015). Our results indicate that care should be taken in estimating annual exports in a dynamic area as Fram Strait. Assuming that synoptic observations are representative of the whole year can result in misleading results. Due to the factors discussed above, the mooring approach (using year-round continuous velocity measurements) provides an improved baseline from which to calculate budgets and observe change. For the period with overlapping estimates (2009-2017) the coefficient of variation in the annual DOC flux estimate was $45 \%$ for the synoptic approach but reduced to $25 \%$ with the mooring approach. Mooring based DOC fluxes were reasonably constant for the period of 2003-2014 and have decreased slightly in recent years (Fig 3c). The average for the first twelve years of the time series is $46.8( \pm 6.2) \mathrm{Tg} \mathrm{yr}^{-1}$ while the last three years fluxes

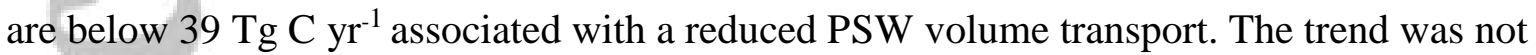
significantly correlated to regional indices (e.g., Arctic Oscillation and North Atlantic Oscillation). Ongoing analysis of the ocean transport time series will allow us to evaluate the process behind it, e. g., changes in regional wind or upstream forcing. Combined with improved observations at other Arctic gateways this will move toward resolving the net effects of processes in the Arctic basin on DOC exports. 


\section{Perspectives}

The CDOM-DOC model developed here holds promise for developing DOC estimates from in situ measurements in a wide variety of environments. For example, spectroscopic nitrate sensors are now readily available and suitable for deployment on moorings and autonomous profilers in lakes and oceans. These instruments collect ultraviolet (UV) attenuation spectra to quantify the absorption band by nitrate in the deep UV. The spectral data used in this paper is collected in the same waveband, so it is likely that the technology can be adapted to provide reasonable high temporal and spatial resolution DOC estimates. If combined on existing mooring arrays, and other autonomous platforms in the Arctic Ocean, it would allow us to further refine estimates of ocean organic carbon transports between basins and quantify changes, especially with regards to seasonal variability. The path is paved to improve the carbon transports by with higher temporal resolution in measurements of CDOM and/or DOC across the EGC, and with technological developments this may soon be possible. This is particularly relevant for key remote regions undergoing considerable change such as the Arctic, and this study provides a baseline that can be used to evaluate future change in carbon transports with the EGC.

\section{Acknowledgements}

This work is a contribution from the Norwegian Polar Institute's Arctic Outflow Observatory in Fram Strait. We like to thank the captains and crews of RV Lance and RV Kronprins Haakon for support during the expeditions. RG-A has received funding from the European Union's Horizon 2020 research and innovation programme under the Marie Skłodowska-Curie grant agreement No. 839311. CAS has received funding from the Independent Research Fund Denmark Grant No. 9040-00266B. CLO acknowledges support for this work from a US Fulbright Specialist position at the Technical University of Denmark. MAG received support for this work from the Polish-Norwegian Research Programme operated by the National Centre for Research and Development under the Norwegian Financial Mechanism 2009-2014 in the frame of project contract Pol-Nor/197511/40/ 2013, CDOM-HEAT. LdS and MAG were supported by the Norwegian Polar Institute. Data used are available at https://doi.org/10.21334/npolar.2020.05173a5f, https://doi.org/10.21334/npolar.2018.9e01 a801 and https://doi.org/10.21334/npolar.2020.1082d329.

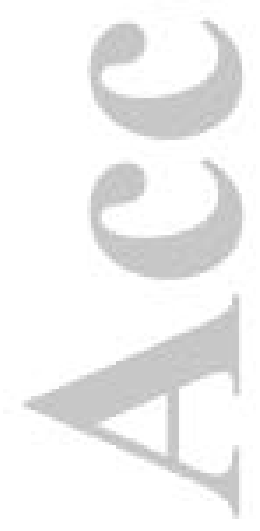




\section{References}

Aarnos, H., Ylöstalo, P., and Vähätalo, A. V. (2012). Seasonal phototransformation of dissolved organic matter to ammonium, dissolved inorganic carbon, and labile substrates supporting bacterial biomass across the Baltic Sea. J. Geophys. Res. Biogeosciences, 117. https://doi.org/10.1029/2010JG001633

Amon, R. M. W. (2004). The role of dissolved organic matter for the organic carbon cycle in the Arctic Ocean. In R. S. Stein \& R. W. Macdonald (Eds.), The Organic Carbon Cycle in the Arctic Ocean (pp. 83-99). New York, NY: Springer.

Anderson, L. G. (2002). DOC in the Arctic Ocean. In D.A. Hansell \& C. A. Carlson (Eds.), Biogeochemistry of Marine Dissolved Organic Matter (pp. 665-683). San Diego, CA: Academic Press.

Anderson, L. G., \& Amon, R. M. W. (2015). DOM in the Arctic Ocean. In Dennis A. Hansell \& C. A. Carlson (Eds.), Biogeochemistry of Marine Dissolved Organic Matter (2nd ed., pp. 609-633). San Diego, CA: Academic Press.

Arrigo, K., \& van Dijken, G. (2011). Secular trends in Arctic Ocean net primary production. Journal of Geophysical Research, 116(C9), C09011. https://doi.org/ 10.1029/2011JC007151

Benner, R., Louchouarn, P., \& Amon, R. M. W. (2005). Terrigenous dissolved organic matter in the Arctic Ocean and its transport to surface and deep waters of the North Atlantic. Global Biogeochemical Cycles, 19(2), n/a-n/a. https://doi.org/10.1029/2004GB002398

Dai, M., Yin, Z., Meng, F., Liu, Q., \& Cai, W.-J. (2012). Spatial distribution of riverine DOC inputs to the ocean: an updated global synthesis. Current Opinion in Environmental Sustainability, 4(2), 170-178. https://doi.org/10.1016/j.cosust.2012.03.003

Dittmar, T., \& Kattner, G. (2003). The biogeochemistry of the river and shelf ecosystem of the Arctic Ocean: a review. Marine Chemistry, 83(3-4), 103-120. https://doi.org/10.1016/S03044203(03)00105-1

Dodd, P. A., Rabe, B., Hansen, E., Falck, E., Mackensen, A., Rohling, E., et al. (2012). The freshwater composition of the Fram Strait outflow derived from a decade of tracer measurements. Journal of Geophysical Research: Oceans, 117(C11). https://doi.org/10.1029/2012JC008011

Engel, A., Bracher, A., Dinter, T., Endres, S., Grosse, J., Metfies, K., et al. (2019). Inter-Annual Variability of Organic Carbon Concentration in the Eastern Fram Strait During Summer (20092017). Frontiers in Marine Science, 6(MAR), 1-17. https://doi.org/10.3389/fmars.2019.00187

Fahrbach, E., Meincke, J., Østerhus, S., Rohardt, G., Schauer, U., Tverberg, V., \& Verduin, J. (2001). Direct measurements of volume transports through Fram Strait. Polar Research, 20(2), 217-224. https://doi.org/10.1111/j.1751-8369.2001.tb00059.x

Fichot, C. G., \& Benner, R. (2011). A novel method to estimate DOC concentrations from CDOM absorption coefficients in coastal waters. Geophysical Research Letters, 38(3). https://doi.org/10.1029/2010GL046152

Gonçalves-Araujo, R., Stedmon, C. A., Heim, B., Dubinenkov, I., Kraberg, A., Moiseev, D., \& Bracher, A. (2015). From Fresh to Marine Waters: Characterization and Fate of Dissolved Organic Matter in the Lena River Delta Region, Siberia. Frontiers in Marine Science, 2, 108. https://doi.org/10.3389/fmars.2015.00108

Gonçalves-Araujo, R., Granskog, M. A., Bracher, A., Azetsu-Scott, K., Dodd, P. A., \& Stedmon, C. A. (2016). Using fluorescent dissolved organic matter to trace and distinguish the origin of Arctic surface waters. Scientific Reports, 6, 33978. https://doi.org/10.1038/srep33978

Gonçalves-Araujo, R., Rabe, B., Peeken, I., \& Bracher, A. (2018). High colored dissolved organic matter (CDOM) absorption in surface waters of the central-eastern Arctic Ocean: Implications for biogeochemistry and ocean color algorithms. PLOS ONE, 13(1), e0190838.

https://doi.org/10.1371/journal.pone.0190838 
Granskog, M. A., Stedmon, C. A., Dodd, P. A., Amon, R. M. W., Pavlov, A. K., de Steur, L., \& Hansen, E. (2012). Characteristics of colored dissolved organic matter (CDOM) in the Arctic outflow in the Fram Strait: Assessing the changes and fate of terrigenous CDOM in the Arctic Ocean. Journal of Geophysical Research, 117(C12), C12021. https://doi.org/10.1029/2012JC008075

Granskog, M. A., Pavlov, A. K., Sagan, S., Kowalczuk, P., Raczkowska, A., \& Stedmon, C. A. (2015). Effect of sea-ice melt on inherent optical properties and vertical distribution of solar radiant heating in Arctic surface waters. Journal of Geophysical Research: Oceans, 120(10), 7028-7039. https://doi.org/10.1002/2015JC011087

Helms, J. R., Stubbins, A., Ritchie, J. D., Minor, E. C., Kieber, D. J., \& Mopper, K. (2008). Absorption spectral slopes and slope ratios as indicators of molecular weight, source, and photobleaching of chromophoric dissolved organic matter. Limnology and Oceanography, 53(3), 955-969. https://doi.org/10.4319/lo.2008.53.3.0955

Opsahl, S., Benner, R., \& Amon, R. M. W. (1999). Major flux of terrigenous dissolved organic matter through the Arctic Ocean. Limnology and Oceanography, 44(8), 2017-2023. https://doi.org/10.4319/lo.1999.44.8.2017

Parmentier, F. J. W., Christensen, T. R., Rysgaard, S., Bendtsen, J., Glud, R. N., Else, B., et al. (2017). A synthesis of the arctic terrestrial and marine carbon cycles under pressure from a dwindling cryosphere. Ambio, 46, 53-69. https://doi.org/10.1007/s13280-016-0872-8

Pavlov, A. K., Granskog, M. A., Stedmon, C. A., Ivanov, B. V, Hudson, S. R., \& Falk-Petersen, S. (2015). Contrasting optical properties of surface waters across the Fram Strait and its potential biological implications. Journal of Marine Systems, 143, 62-72. https://doi.org/10.1016/j.jmarsys.2014.11.001

Rabe, B., Dodd, P. A., Hansen, E., Falck, E., Schauer, U., Mackensen, A., et al. (2013). Liquid export of Arctic freshwater components through the Fram Strait 1998-2011. Ocean Science, 9(1), 91109. https://doi.org/10.5194/os-9-91-2013

Raymond, P. A., McClelland, J. W., Holmes, R. M., Zhulidov, A. V., Mull, K., Peterson, B. J., et al. (2007). Flux and age of dissolved organic carbon exported to the Arctic Ocean: A carbon isotopic study of the five largest arctic rivers. Global Biogeochemical Cycles, 21(4), 1-9. https://doi.org/10.1029/2007GB002934

Romera-Castillo, C., Sarmento, H., Álvarez-Salgado, X, Gasol, J.M., Marrasé, C. (2010). Production of chromophoric dissolved organic matter by marine phytoplankton. Limnol. Oceanogr., 55(1), 446-454. https://doi.org/ 10.4319/lo.2010.55.1.0446

Rudels, B., J. Friedrich, H., \& Quadfasel, D. (1999). The Arctic Circumpolar Boundary Current. Deep Sea Research Part II: Topical Studies in Oceanography, 46(6-7), 1023-1062. https://doi.org/10.1016/S0967-0645(99)00015-6

Sakshaug, E., Stein, R., \& Macdonald, R. W. (2004). Primary and secondary production in the Arctic Seas. In R. Stein \& R. W. Macdonald (Eds.), The Organic Carbon Cycle in the Arctic Ocean (pp. 57-82). Springer.

Schauer, U., \& Losch, M. (2019). "Freshwater" in the Ocean is Not a Useful Parameter in Climate Research. Journal of Physical Oceanography, 49(9), 2309-2321. https://doi.org/10.1175/JPOD-19-0102.1

Schlitzer, R. (2016). Ocean Data View. Retrieved from http://odv.awi.de

Spencer, R. G. M., Butler, K. D., \& Aiken, G. R. (2012). Dissolved organic carbon and chromophoric dissolved organic matter properties of rivers in the USA. Journal of Geophysical Research: Biogeosciences, 117(G03001), 1-14. https://doi.org/10.1029/2011JG001928

Stedmon, C. A., \& Nelson, N. B. (2015). The optical properties of DOM in the ocean. In D A Hansell \& C. A. Carlson (Eds.), Biogeochemistry of Marine Dissolved Organic Matter (pp. 481-508). San Diego, CA: Elsevier Inc.

Stedmon, C. A., Granskog, M. A., \& Dodd, P. A. (2015). An approach to estimate the freshwater contribution from glacial melt and precipitation in East Greenland shelf waters using colored 
dissolved organic matter (CDOM). Journal of Geophysical Research: Oceans, 120(2), 11071117. https://doi.org/10.1002/2014JC010501

Stein, R., \& Macdonald, R. W. (2004). Organic carbon budget: Arctic vs. Global ocean. In R. Stein \& R. W. Macdonald (Eds.), The Organic Carbon Cycle in the Arctic Ocean. Berlin, Heidelberg: Springer-Verlag. https://doi.org/10.1007/978-3-642-18912-8

de Steur, L., Hansen, E., Mauritzen, C., Beszczynska-Möller, A., \& Fahrbach, E. (2014). Impact of recirculation on the East Greenland Current in Fram Strait: Results from moored current meter measurements between 1997 and 2009. Deep-Sea Research Part I: Oceanographic Research Papers, 92, 26-40. https://doi.org/10.1016/j.dsr.2014.05.018

de Steur, L., Peralta-Ferriz, C., \& Pavlova, O. (2018). Freshwater Export in the East Greenland Current Freshens the North Atlantic. Geophysical Research Letters, 45(24), 13,359-13,366. https://doi.org/10.1029/2018GL080207

Tanski, G., Wagner, D., Knoblauch, C., Fritz, M., Sachs, T., \& Lantuit, H. (2019). Rapid CO2 Release From Eroding Permafrost in Seawater. Geophysical Research Letters, 46(20), 11244 11252. https://doi.org/10.1029/2019GL084303

Vodacek, A., Blough, N. V, DeGrandpre, M. D., Peltzer, E. T., \& Nelson, R. K. (1997). Seasonal variation of CDOM and DOC in the Middle Atlantic Bight: Terrestrial inputs and photooxidation. Limnology and Oceanography, 42(4), 674-686.

Vonk, J. E., \& Gustafsson, Ö. (2013). Permafrost-carbon complexities. Nature Geoscience, 6(9), 675676. https://doi.org/10.1038/ngeo1937

Vonk, J. E., Sánchez-García, L., van Dongen, B. E., Alling, V., Kosmach, D., Charkin, A., et al. (2012). Activation of old carbon by erosion of coastal and subsea permafrost in Arctic Siberia. Nature, 489(7414), 137-140. https://doi.org/10.1038/nature11392

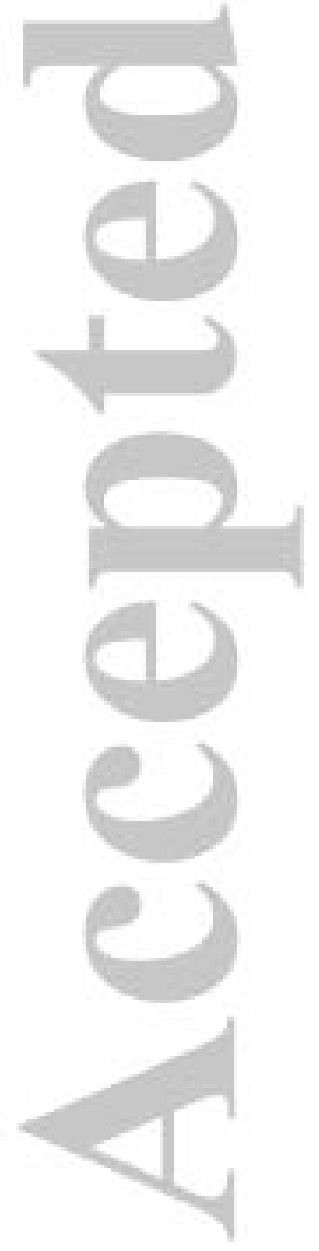



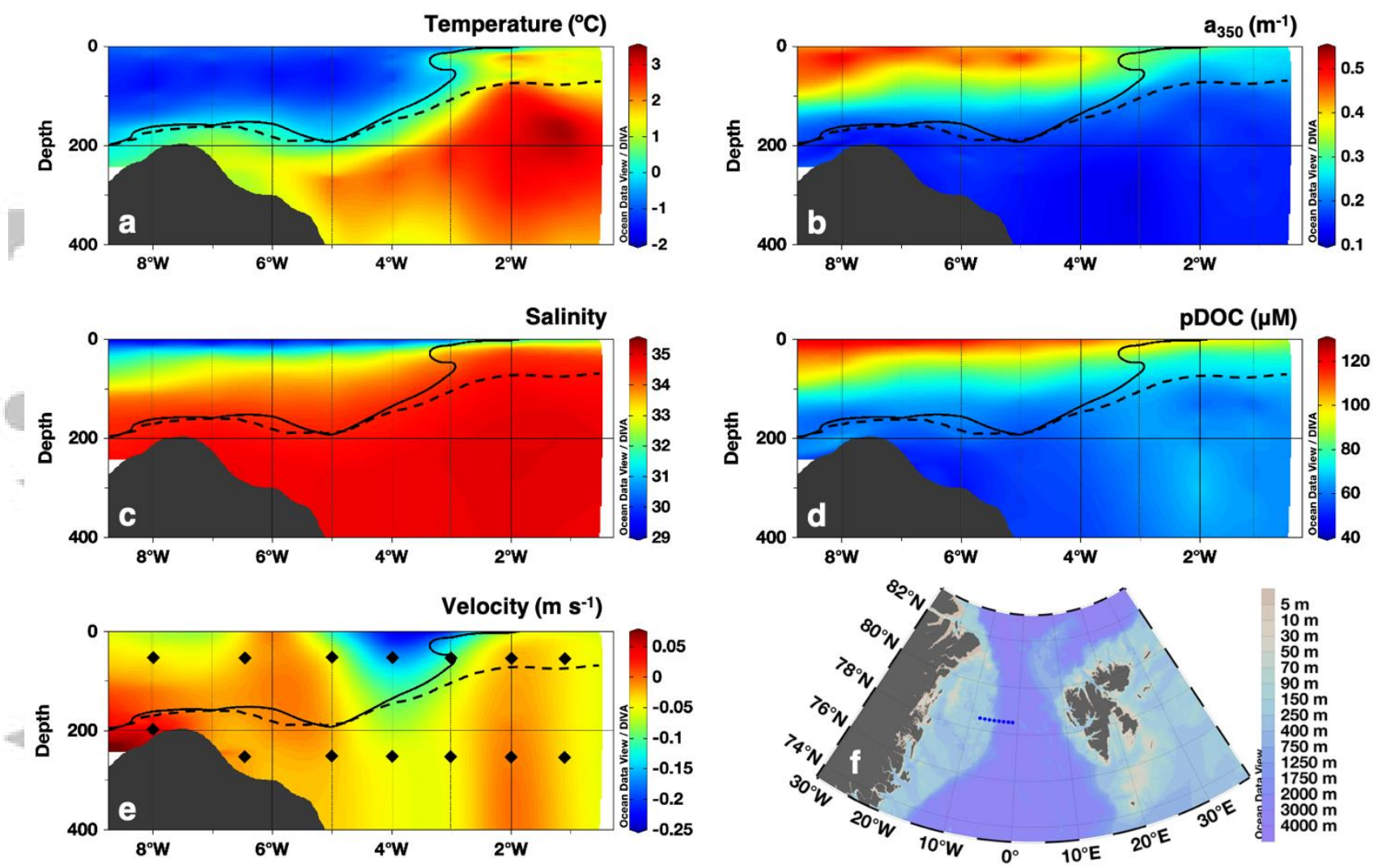

Figure 1. Mean sections of (a) temperature $\left({ }^{\circ} \mathrm{C}\right),(\mathbf{b}), \mathrm{CDOM}$ absorption at $350 \mathrm{~nm}\left(\mathrm{a}_{350}, \mathrm{~m}^{-1}\right),(\mathbf{c})$ salinity, (d) predicted DOC (pDOC; $\mu \mathrm{M})$ and (e) absolute geostrophic velocity $\left(\mathrm{m} \mathrm{s}^{-1}\right)$ for the section presented in the map, where negative values indicate southward velocities (f). Panels show the mean obtained from averaging the synoptic sections from years 2009 to 2018. The black solid lines depict the $0{ }^{\circ} \mathrm{C}$ isothermal, the dashed lines show the $27.7 \mathrm{~kg} \mathrm{~m}^{-3}$ isopycnal used to distinguish Polar Surface Water (PSW). Black diamonds in (e) illustrate target locations and target depths for the moored instruments, which coincide with oceanographic stations where CTD casts and water sampling were performed. The map shows the target locations where ocean moorings were deployed from 2003 to 2018. Produced with Ocean Data View (Schlitzer, 2016). 

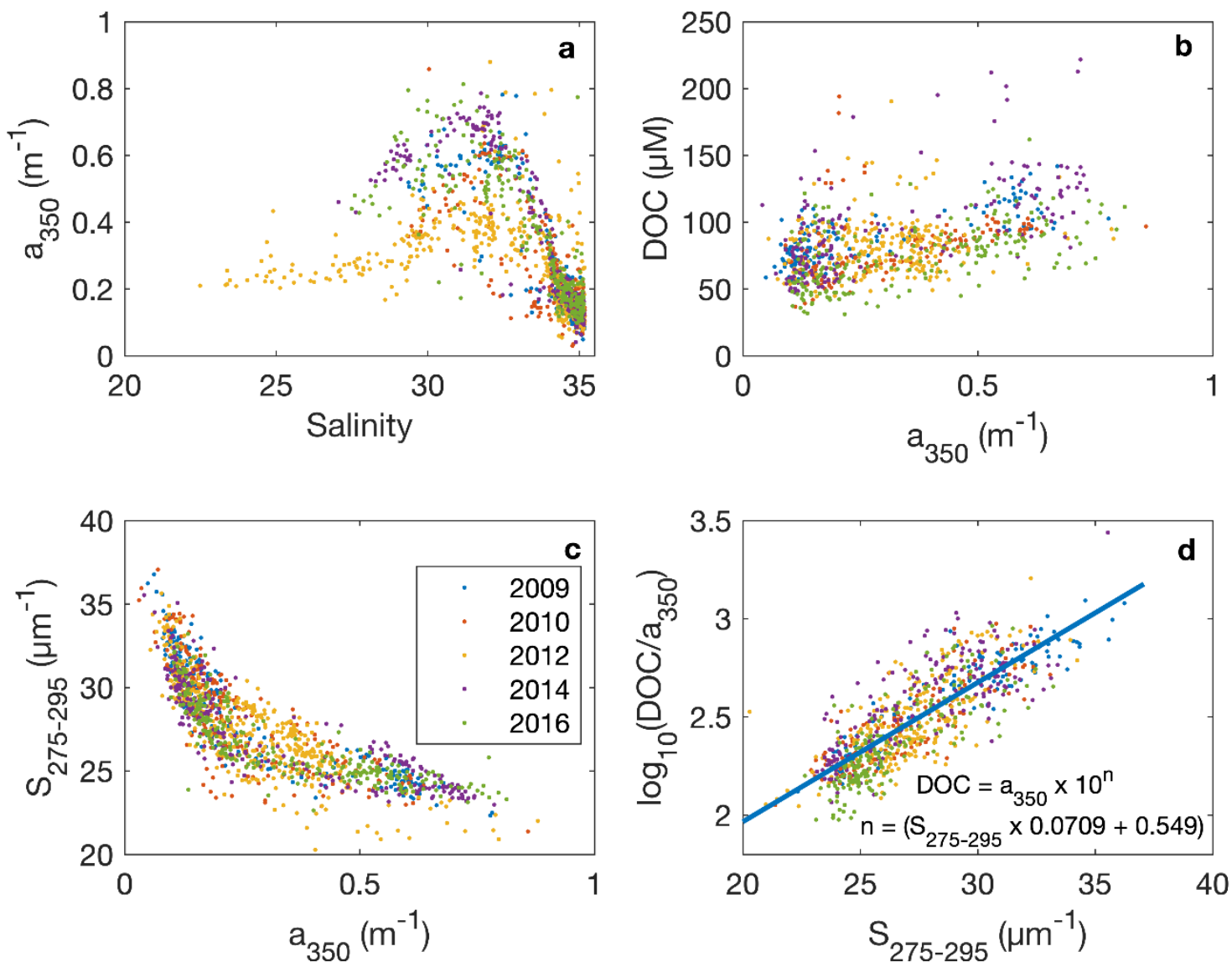

Figure 2. Relationships between (a) salinity and CDOM absorption, (b) CDOM absorption and DOC, (c) CDOM absorption and spectral slope and (d) $\log _{10}\left(\mathrm{DOC} / \mathrm{a}_{350}\right)$ and $\mathrm{S}_{275-295}$, across the whole Fram Strait section for years with available DOC data. The relationship in (d) was used to extrapolate DOC measurements to cover the entire strait for all years. 

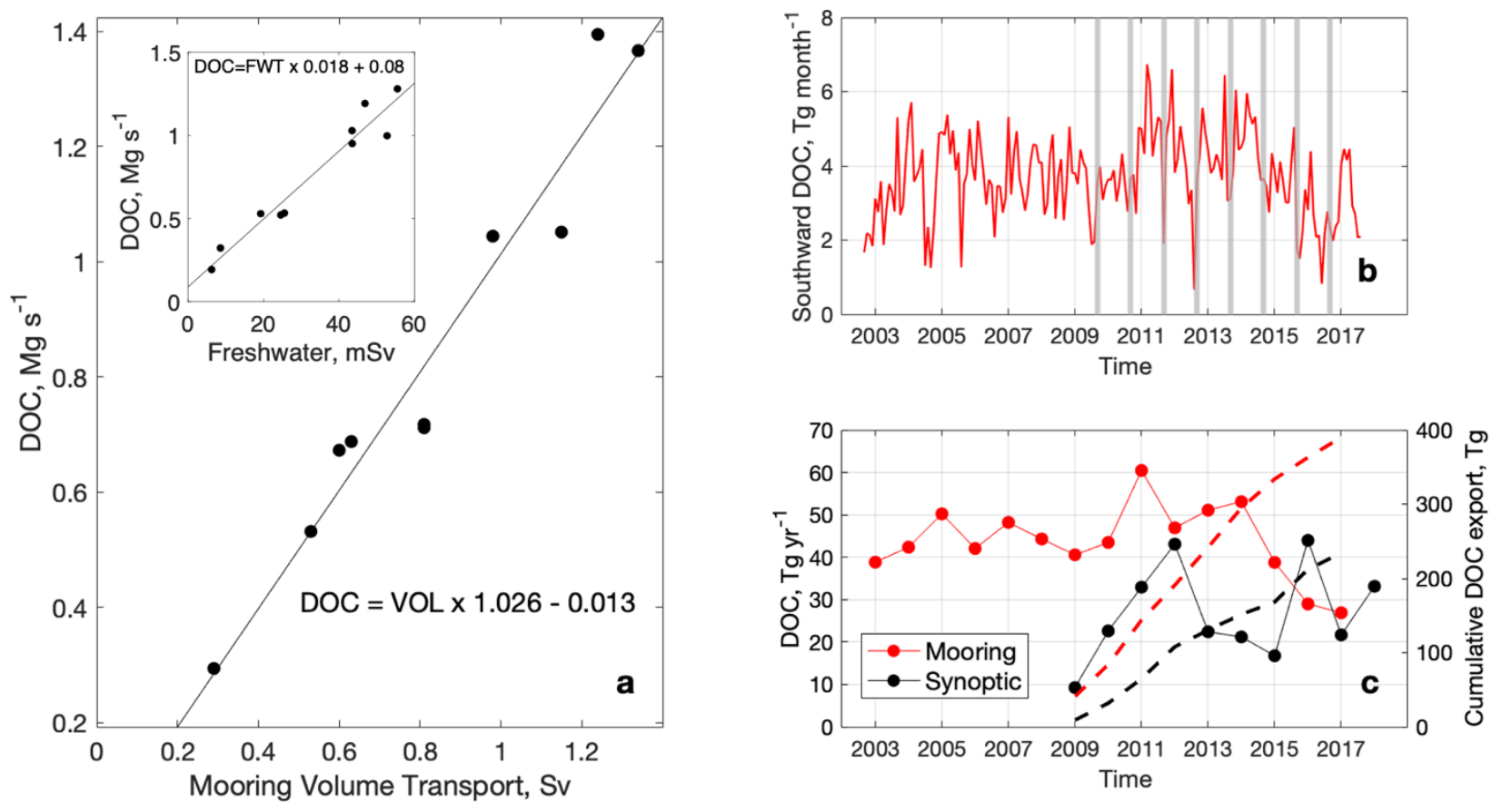

Figure 3. (a) Relationship of mean PSW volume transport from moorings (VOL) and synoptic DOC transport (derived from absolute geostrophic velocities) in the EGC for August/September 2009-2018 (DOC $=$ VOL $\times 1.026-0.013 ; r=0.97 ; p<0.0001)$. Inset graph shows the relationship between synoptic DOC transport and freshwater transport with PSW (FWT; relative to temperature $<0{ }^{\circ} \mathrm{C}$ and density $<27.7 \mathrm{~kg} \mathrm{~m}^{-3}$ ) in the EGC for August/September 2009-2018 $(\mathrm{DOC}=\mathrm{FWT} \times 0.018+0.08 ; r=0.94 ; p<0.0001)$. (b) Monthly DOC southward transports with PSW (red) with the EGC estimated using the time series of VOL based on mooring data and the equation obtained in (a) with the FS cruises indicated with vertical gray. (c) Annual mean (solid lines) and cumulative (2009-2017; dashed lines) PSW DOC export in the EGC using monthly VOL as a proxy (red) compared with estimates based on synoptic sections (black) extrapolated to the whole year. 
Table 1. Summary of observations and estimates in the Fram Strait and PSW in EGC. Mean (minimum-maximum) values for parameters (DOC, a $350, \mathrm{~S}_{275-295}$ ) measured in the Fram Strait (spanning the whole Fram Strait). Southward transports of Polar Surface Water (PSW) estimated within the EGC $\left(1-8{ }^{\circ} \mathrm{W}\right.$; temperature $<0{ }^{\circ} \mathrm{C}$ and density $\left.<27.7 \mathrm{~kg} \mathrm{~m}^{-3}\right)$. Note that here we present the mean southward transports for August/September only (for both mooring volume and synoptic DOC) and the annual DOC export obtained with both synoptic and mooring approaches. Annual mooring DOC southward transport estimates for 2018 is not available (n/a) since the moorings were serviced in 2019 and data is not yet processed.

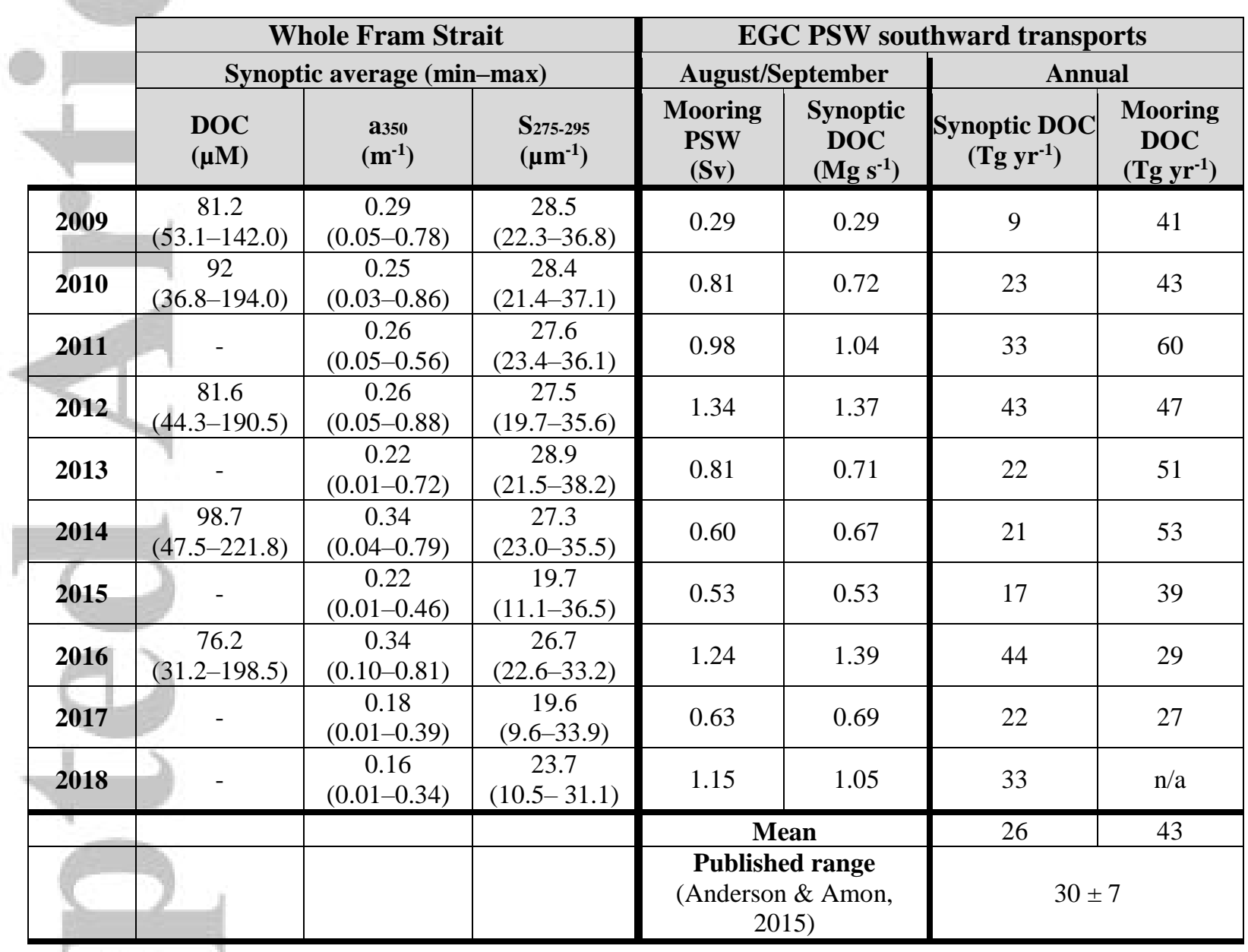

